\title{
Diacronie
}

Studi di Storia Contemporanea

$N^{\circ} 9,1 \mid 2012$

Quando la classe operaia andava in paradiso

\section{The French Socialist and German Social Democratic Parties and the Future of the Working Class in the European Coal \& Steel Community,} 1948-1954

\section{Brian Shaev}

\section{(2) OpenEdition Journals}

Electronic version

URL: http://journals.openedition.org/diacronie/3054

DOI: $10.4000 /$ diacronie.3054

ISSN: 2038-0925

\section{Publisher}

Association culturelle Diacronie

\section{Electronic reference}

Brian Shaev, «The French Socialist and German Social Democratic Parties and the Future of the Working Class in the European Coal \& Steel Community, 1948-1954 ", Diacronie [Online], N 9, 1 | 2012 , document 13, Online since 29 January 2012, connection on 19 April 2019. URL : http:// journals.openedition.org/diacronie/3054; DOI : 10.4000/diacronie.3054 


\section{Diacronie}

N. 9 | 1 |2012 Quando la classe operaia andava in paradiso

\section{3/}

\section{The French Socialist and German Social Democratic Parties and the Future of the Working Class in the European Coal \& Steel Community, 1948-1954}

Brian SHAEV*

Although the status of workers in the European Coal \& Steel Community (ECSC) was not the determining factor in French Socialist (SFIO) and German Social Democratic (SPD) policy towards the Schuman Plan, the two parties made sustained efforts to protect workers' interests within the Community. During the Schuman Plan debates, SPD leaders argued that they had higher chances of enacting a program of full employment and socialization at the national level, rather than within a supranational community, while the SFIO leaders concluded that the High Authority would strengthen the influence of workers in the coal and steel industries. After ECSC ratification, the SFIO and SPD criticized the paucity of the ECSC's social achievements, and consistently pressured the High Authority to enforce the social provisions of the Treaty of Paris. 
$\mathrm{A}$

$\mathrm{s}$ the French National Assembly concluded its debate on the ratification of the accords to institute a European Coal and Steel Community (ECSC) in December 1951, Socialist deputy Guy Desson evoked Fritz Lang's dystopian film Metropolis to argue that the Assembly had not devoted sufficient attention to the prospects of workers in the proposed Community. He declared:

We have spoken much of coal. We have spoken much of steel. But although the balance between these two important factors of the economy has been kept in balance, we have greatly neglected those who extract the coal and minerals, those who make the steel. ${ }^{1}$

Although Desson admitted that he may have exaggerated when he spoke of not wanting to see established in France «these gigantic termite mounds where colonies of workers live at the prey of a managerial organization $»^{2}$, his critique was in large part accurate: the position of coal and steel workers was not central to the French National Assembly's debate on the ECSC. In addition, it was not the determining factor for Desson's party, the French Socialist Party (SFIO), when the party decided that it would support the ECSC. Although he went on to argue that the ECSC would be beneficial to workers, a comment by Socialist Léon Boutbien, charged with presenting the National Assembly Labor Commission's recommendation on the ECSC, is illustrative of the relative subordination of workers' interests in the debate:

When it comes to replacing a policy of hatred with a policy of effective collaboration between peoples, we have every reason to believe that the workers of France will not remain indifferent to such preoccupations. ${ }^{3}$

The ECSC was designed principally to establish a basis for the «organized cooperation» 4 and reconciliation between the French and German governments, and to assure an adequate supply of German coal for French industry. As such, the position of workers was also of secondary consideration in the debate that occurred in West Germany. Much more prominent in the French and German parliamentary debates

\footnotetext{
${ }^{1}$ Journal officiel (JO) 1951 9008. December 11, 1951. Desson voted with his party in support of the ECSC.

${ }^{2}$ Ibid.

3 Ibid. 8871, December 6, 1951.

4 WILLIS, Roy, France, Germany, and the New Europe: 1945-1967, Stanford, Stanford University Press, 1968.
} 
from 1950 to early 1952 were concerns about the ability of French and German industries to compete in a tariff-free coal and steel community, the self-exclusion of Great Britain and Scandinavia, the assertion of democratic controls over the Community's institutions, the long-standing antagonism between the French and German governments, and geopolitical concerns rooted in early Cold War politics.

This article investigates how the French Socialist Party and German Social Democratic Party (SPD) envisioned the position of coal and steel workers in the ECSC. These parties presented themselves as advocates for industrial workers and were in constant competition for the allegiance of the working class with the French Communist (PCF) and German Communist (KPD) parties. With much of their attention consumed by the rapid series of events in a period that included the Berlin blockade, the creation of a West German state, and the launch of the Korean War, it is perhaps understandable that the interests of workers in France and Germany's principal industrial regions were not the central factors in Socialist deliberations on the Schuman Plan. It is therefore also not surprising that the secondary literature on the policies of the SFIO and SPD toward early European integration initiatives does not discuss in detail how these parties worked to fulfill their programmatic role as defenders of the working class during the debates on the ECSC.

However, although these parties did not place workers at the center of their response to Robert Schuman's proposal of 9 May 1950, their influence was important for their governments' decisions to insert protections for workers into the treaty. It is therefore worth considering how SFIO and SPD economic and industrial goals during the period preceding Schuman's announcement informed the parties' views of the Community's likely impact on workers. This article begins by discussing the parties' assessments of the position of workers under proposals for European integration from 1948 to 1950, and then analyzes how these positions informed the SFIO's support for and the SPD's opposition to the ECSC from 1950 until the Bundestag's ratification of the Treaty of Paris in January 1952. There follows an examination of the concerns and pressure French Socialists and German Social Democrats exerted in the Common Assembly of the ECSC in their defense of industrial workers during the initial period of the Community's existence from 1952 to 1954. 


\section{SFIO and SPD Industrial and Economic Policy, 1948-1949}

In the late 1940 s both the French Socialists and German Social Democrats were in a pitched rhetorical and grass-roots battle with the French and German Communist parties, which SFIO and SPD leaders accused of pursuing a subversive campaign to undermine democracy. As strikes swept industrial France from 1947-1949 and the Ruhr workers vocally displayed a resolute opposition to the Allied policy of dismantling and splitting up German industry, SFIO and SPD leaders worried that unemployment and a degradation in workers' living standards could result in a radicalization of the working class. In this context, the parties' traditional assertion of the need for programs to achieve full employment received an added urgency.

On this issue the SFIO and SPD were in agreement: full employment must be the policy of their governments and should be at the center of any European-level recovery plan. In fall 1949 and spring 1950 the Socialist parties of Europe met numerous times to craft a united industrial policy. The SFIO submitted a "Report on the Mobility of Labor" to the September 1949 meeting of the COMISCO, a precursor to the reconstructed Socialist International, in which the party argued for a semi-planned economy with full employment, defined, following William Beveridge's influential wartime study, as an unemployment rate under $3 \%$ of the active population 5 . The SPD shared the SFIO's concern, and asserted that the conference should call for a wage, price, and production policy designed to achieve full employment ${ }^{6}$. When COMISCO held a meeting of Socialist economic experts in late March 1950 in the Ruhr, the delegates were unanimous in support of industrial investment programs centered on the goal of full employment7. Such a policy was particularly pressing for French Socialists and German Social Democrats because both parties pointed to signs that the working class was losing ground in terms of wages and influence as the governments shifted to the right in France and Germany. In addition, grass-roots labor mobilization around the call for co-determination in the management of industry in the Ruhr area made this demand a defining feature of SPD industrial policy.

Although both the SFIO and SPD leaderships shared many economic goals and initially reacted to Schuman's 1950 announcement with hesitation and non-

5 Archiv der sozialen Demokratie (AdsD), 2/PVBT3, SFIO Rapport sur la mobilité de la main d'oeuvre.

${ }^{6}$ Kurzer Bericht zur Sachverständigenkonferenz des COMISCO vom 11.-16. September 1949 in Oerenaes/Schweden. September, 24 1949. Ibid.

7 AdsD, 2/PVBT4, Witten/Ruhr von 26./31./ März 1950, Bericht über die Tagung der COMISCO-Wirtschaftsexperten. 
commitment, the positions that these parties eventually adopted on the ECSC were consistent with the logic of the policies that they had crafted in 1948-1949 in response to the proposals for an International Authority of the Ruhr (IAR). The SFIO and SPD both rejected the punitive German policy of the French governments of 1945 to 1947. They did not, however, agree about the best means of preventing the re-concentration of power in the hands of industrial magnates who, they argued, had assisted Adolf Hitler's rise to power. The attention of the Allied governments from 1946 to 1950 was fixated on the future of the Ruhr territory, the heart of Europe's coal and steel industries, and the arsenal for the Nazis' militarization of Germany. German Social Democrats adamantly asserted the need to prevent a restitution of the Ruhr mines and steel factories to their former owners and presented the socialization of these heavy industries as the only possible solution.

French Socialists, however, were not satisfied that the socialization or nationalization of German heavy industry would suffice to prevent the region from yet again being exploited by a German government for the purposes of war. Crucially, the SFIO leadership shared the goals of Jean Monnet's Planning Commission, which had embarked on the renovation and expansion of France's industrial capacity. The central obstacle to the modernization of French industry, however, was a shortage of coal and, as Jean Monnet and his entourage argued time and again, the coal imports that France desperately needed could only come from one source: the Ruhr. Therefore, due to both economic factors and apprehension about the future intentions and composition of a future German government, the SFIO leadership asserted that the internationalization, rather than socialization, of the Ruhr was necessary to assure French national and economic security.

This disagreement, and the controversial status of the Saar, which was detached from Germany and entered into economic union with France, poisoned relations between the SFIO and the SPD. German Social Democrats raised a series of objections to the International Authority of the Ruhr, which was formally set up in August 1949, the month when the Federal Republic of Germany became a state. The SPD critique focused largely around the continuation of the policy of dismantling factories. In the SPD's view, the IAR's policy in effect blocked the chances for socialization within West Germany. For SPD leader Kurt Schumacher, socialization, though a long-term party economic goal, was principally justified in terms of political power. The Ruhr industrial magnates, SPD leaders asserted, must not regain control of the industrial center of West Germany, which they could then use to re-launch German militarism. Turning to 
the occupying powers, Schumacher also denounced that in Allied negotiations the Ruhr «population and its labour [were] regarded as mere objects». He argued:

\begin{abstract}
An authority which represents such a concentration of power has a tremendously strong position as an employer, and what is more, this all-powerful employer is, for the mass of the German workers, clerks and technicians, a foreigner working for foreign interests. Thus the social tensions existing between employers and employees will be intensified by national dissensions. ${ }^{8}$
\end{abstract}

For Schumacher and other SPD leaders, a nationalist struggle reminiscent of the 1923 coal and steel workers' revolt against the French occupation of the Ruhr would divert workers' attention from the class struggle. In addition, the displacement of authority from the factories to an international body would create an additional obstacle to German workers' campaign for co-determination in management. This critique that workers' influence would be diluted by the IAR was resurrected in the SPD's later campaign against the Schuman Plan.

Faced with the liberalization of trade under the auspices of the Organization for European Economic Cooperation (OEEC), both the SFIO and SPD worried that their national industries would enter a free trade environment at a disadvantage. German Social Democrats argued that industrial dismantlement in Germany, coupled with the sustained industrial investment program in France, had resulted in a great loss in the competitive potential of the Ruhr area. For the French Socialists, the concern was different. Party economist André Philip argued to the party's National Council in 1948 that, «The day one eliminates customs barriers without having done the preparatory work, the least profitable businesses will eliminate the others through competition», which will result in unemployment and idle machinery. Philip, one of the party's staunchest supporters of trade liberalization and European integration, argued that a «customs union ought to be accompanied by the unity of legislation as it concerns fiscal policy, salaries, social security and monetary policy»9. The demand for the harmonization of social policies became a staple of French Socialist policy towards proposals for European unity through the 1950s.

Faced with proposals for a customs union with Italy and the Benelux countries in late 1949, French Socialist Francis Leenhardt argued that the party must proceed cautiously because Belgium and Italy had higher levels of unemployment and therefore

\footnotetext{
${ }^{8}$ AdsD, Bestand Kurt Schumacher (BKS) 46, «SPD and Ruhr Statute», February 1949.

9 Office universitaire de recherche socialiste (OURS), Conseil national, April 27-8, 1948.
} 
a customs union could result in spiraling unemployment rates in France ${ }^{10}$. Considering this issue at the SFIO's extraordinary National Congress in December, Socialist Christian Pineau, the future foreign minister who oversaw the negotiations for the Treaties of Rome, argued that without an economic organization, the liberalization of trade would result in "the countries with the worst social conditions having an advantage compared with those with better social conditions» a situation that would result in the «invasion of foreign products against French industry [...] that would lead us [...] to extract margins from the working class» in order to remain competitive. This would be particularly alarming if «we find ourselves one day faced with German competition that has equipment superior to our own, [and] with workers paid less than we». Guy Mollet, while declaring his support for Germany's integration into the Western economy, declared that «I will not accept [...] that a country could benefit from not having realized the same social conditions for its proletariat (and through) distorted competition, with a sort of dumping, come to compete and throw the French worker into unemployment» ${ }^{11}$.

Both parties, however, generally supported the liberalization of trade as a means to advance European unity and modernize industry but argued that state planning and investment programs to ensure full employment must accompany any liberalization. Hence, when Schuman announced his plan in May 1950, the contours for what would be the French Socialist and German Social Democratic view of the likely impact of the ECSC on workers were already in place. While both parties advocated a forceful statesponsored policy of full employment and supported in principle the lowering of tariffs, the SPD worried that international management would hamper coal and steel workers' struggle for socialization and co-determination, and the SFIO argued that French workers would suffer increased unemployment unless the social spending of its neighbors was raised to the levels prevailing in France.

\section{Coal and Steel Workers in French Socialist and German Social Democratic Debates on the Schuman Plan, May 1950-January 1952}

Although there were enthusiastic supporters among the leadership of both parties, the SFIO and the SPD reacted cautiously to Schuman's 9 May 1950 proposal. While the central committees of both parties issued statements welcoming the plan in principle, they reserved their position until they could see its details. Over the next six months,

10 OURS, Comité directeur, November 10, 1949.

${ }^{11}$ OURS, Congrès national extraordinaire, December 13-14, 1949. 
the assessments of the two parties diverged: the SFIO came to publicly support the plan and objected to the strenuous opposition first announced by Kurt Schumacher in October 1950. The possible impact of Schuman's proposal on coal and steel workers was not the principal issue around which internal party debates on the ECSC developed. In fact, there is no record of a discussion of the plan's possible impact on the working class in the minutes of the SFIO central committee meeting of 10 May 1950, nor did the party mention workers in the list of conditions that it published as a result of this meeting ${ }^{12}$. Kurt Schumacher, on the other hand, raised the issue of codetermination on 11 May 1950 and argued that the trade unions must play important roles in the proposed supranational institutions ${ }^{13}$.

Over the next year and a half the German Social Democrats developed a comprehensive and multifaceted critique of the Schuman Plan and conducted a passionate campaign to defeat the treaty. Among their objections were assertions that the managerial influence that coal and steel workers had attained after the war, an influence that was codified and expanded by the May 1951 law that guaranteed codetermination in industry, would decline under a supranational authority. The SPD leadership displayed a marked suspicion towards the proposed High Authority, the brainchild of Jean Monnet, who led France's modernization program. In the ratification debate of January 1952, SPD deputy Willi Birkelbach asserted that the presence of workers' representatives in the Advisory Committee, "whose name itself gives expression to its meaningless», represented a decline in workers' influence vis-àvis management. Schumacher's successor as SPD chair, Erich Ollenhauer, stated that the presence of at most one trade unionist on the High Authority was a setback compared to the voice that workers had obtained in West Germany ${ }^{14}$. In April 1951 the SPD published a pamphlet entitled What do you know about the Schuman Plan? that laid out the argument that the beneficiary of the proposal «is the international coal trade, which will dominate production and working people». That same month SPD deputy Gerhard Lütkens condemned the proposed High Authority, which, in his view, would replace the power of consumer organizations and trade unions with that of employers and technocrats. The proposed Common Assembly was too weak, he argued,

\footnotetext{
12 OURS, Comité directeur, May 10, 1950.

${ }^{13}$ AdsD, BKS 51, «Schumachers Nein zum Europa-Rat: Grund: Gleichzeitiger Beitritt der Saar» May 11, 2011.

14 AdsD, Bestand Erich Ollenhauer (BEO) 77, Übertragung der Rede des 2. Vorsitzenden der SPD Erich Ollenhauer, am 14.4.1951 im Redoutensaal zu Erlangen «Die SPD im Kampf um Freiheit und Gerechtigkeit».
} 
to effectively stymie the combined power of capitalists and supranational bureaucrats ${ }^{15}$. This position led the SPD into conflict with the principal German trade union federation, the DGB, which supported the Schuman Plan.

The SFIO, conversely, came to the conclusion that the High Authority would strengthen the influence of workers. While the SPD argued that the High Authority would exercise a dictatorship over the working class in alliance with employers, Philip viewed the intervention of a supranational body between the workers and management as an advance for workers and a bulwark against employers' power. The contrast in the parties' assessments was, no doubt, in part the consequence of the success of the SPD's campaign for co-determination in Germany, a practice that did not exist in France. Also, the SFIO leaders enjoyed close, personal relations with Jean Monnet and hence believed that the High Authority would not work to solely represent employers' interests. In the French ratification debates, Boutbien declared that he was satisfied with the position granted workers' representatives in the ECSC, though he also wanted to see this position further strengthened. He welcomed that workers shared equal representation with consumers and employers in the Advisory Committee and that the workers' representatives could petition the High Authority. Boutbien asked the French government, though, to seek an agreement to compel the High Authority to consult the Advisory Committee when making any decision concerning salaries, or if one-third of the committee members requested a hearing ${ }^{16}$.

While arguing that the Schuman Plan was nothing more than a renewed attempt to gain French hegemony over the German population and its resources, Schumacher declared to an audience of 60.000 in Dortmund, an industrial city in the Ruhr, that «The Schuman Plan means unemployment!»17. Efforts to disband the German coal distribution cartel would result, according to Ollenhauer, in mass unemployment for miners ${ }^{18}$. SPD speakers argued on numerous occasions that the dismantlement and lack of investment in German industry after the war meant that German coal and steel workers would suffer if placed in competition with their neighbors. When discussing the Schuman Plan in July 1950, Schumacher pointed out that the negotiating countries were «the six countries [in Western Europe] with the lowest wages and highest

15 AdsD, Bestand Willi Eichler 114, SPD-Pressedienst 20 April 1951, Dr. G. Lütkens, «Die Montanunion der 'Festen Hand'».

${ }^{16}$ JO 1951 8871. December 6, 1951.

${ }_{17}$ AdsD, BKS 53, Dortmund 8.10.1950, Kundgebung der 60 ooo auf dem Hansaplatz.

18 AdsD, BEO 77, «Die SPD und der Schuman-Plan». Rede des 2. Vorsitzenden Ollenahuer in Bremen am 18. Juni 1951. 
unemployment»19. A customs union with low-wage countries, rather than with Scandinavia or Great Britain, where social democratic and labor governments were in power, portended the stagnation or decline of wages for German industrial workers.

At a meeting of the Socialist International dedicated to discussing the Schuman Plan, SFIO representative Salomon Grumbach condemned the SPD for asserting that the Schuman Plan would create mass unemployment. Lütkens responded for the SPD that the High Authority's control of resource distribution «made it impossible for certain countries to carry out their own full employment policies». He was not satisfied that Article 2 of the treaty declared full employment as a principal goal of the Community and suggested that amendments to the treaty, including for a body to supervise the High Authority, should be inserted to strengthen its commitment to full employment. Inspired by the examples of the Labour government in Great Britain and Social Democratic governments in Scandinavia, the criticism emanating from the SPD makes it clear that the party leaders believed that they had greater chances of enacting a program of full employment and socialization at the national level rather than within a supranational community. This reflects SPD optimism for the upcoming 1953 national elections, during a period in which the French Socialist Party was suffering a marked decline in membership and votes. Grumbach took aim at the SPD's claim that the ECSC would block socialization, claiming that the SFIO had made clear to its government that it would oppose any treaty that hampered its ability to socialize industry or might threaten the nationalized French coal industry. About his German colleagues, Grumbach stated:

We specifically asked them which articles of the Schuman Plan prevent socialization or workers' participation, and which articles lead to the fear that unemployment would be created. We could not find them. ${ }^{20}$

There were sustained worries within the SFIO as well that unemployment might result from a customs union of coal and steel. At its National Congress a few weeks after the announcement of the Schuman Plan, these fears came to the fore. Unaware that the Korean War would soon break out and generate a dearth of steel during the production boom of 1950-1952, Philip argued that the coal and steel industries were moving towards an overproduction that would conjure increased competition and

19 AdsD, BKS 52, Ansprache Dr. Kurt Schumachers in einer Funktionärversammlung der sozialdemokratischen Partei Deutschlands am 31. Juli 1950 um 17.30 Uhr.

${ }^{20}$ International Institute for Social History (IISH), SI-241, Minutes of the Conference on the Schuman Plan Frankfurt a./M., 27.-28. 1951. 
unemployment as less productive businesses closed. He placed Germany in the center of his analysis: suffering two million unemployed and an exploding trade deficit, Germany would be forced to greatly increase its exports. With salaries and benefits much lower than those of French workers, the liberalization of German coal and steel would lead to "social dumping" and the closure of less productive French coal mines. Particularly threatened, Jouve pointed out, were the mines of the North and Pas-deCalais, while the Lorraine region would remain competitive. Socialist leader Guy Mollet, who represented the Nord, was dismayed that:

This French-German duo will mean the destruction of whichever of the two countries seeks to give a higher standard of living to its proletariat, even if [that country] has not actually done all that much good; it means social dumping, and will give an advantage to that [country] which, at the present moment, makes its workers labor sixty or sixty-five hour work days without social security. ${ }^{21}$

Unlike the SPD, however, the SFIO leaders argued that the solution to these problems lay in strengthening the authority of the supranational authority on social issues. Philip stated that, «It is necessary to organize the heavy industries, coordinate investments; it is necessary that the problem of full employment be posed now on the European plane». The High Authority should be invested with powers to counter the impact of economic liberalism with a salary adjustment fund, a fiscal adjustment fund, organisms to equalize prices, and the coordination of investments in such a way as to ensure full employment ${ }^{22}$. When the Treaty of Paris came up for ratification, Boutbien welcomed that Article Three called for «promoting the amelioration of working conditions, permitting progressive equalization». He went on to argue that social charges in France were not nearly as different from those in Germany as other members of the Assembly had argued ${ }^{23}$. Not all Socialist deputies, however, were as optimistic as Boutbien. Desson spoke of unemployment sweeping certain regions at a rapid pace; Robert Lacoste worried that the transition period for the lowering of tariffs was too short ${ }^{24}$. This danger could be averted by the extension of state investments plans, a demand upon which the SFIO made its vote conditional. These were, of course, the same investment plans that the SPD argued placed German industry at a

${ }^{21}$ OURS, Congrès national, May 26-29, 1950.

22 Ibid.

${ }^{23}$ JO 1951 8871-2. December 6, 1951.

${ }_{24}$ Ibid. 1951 8919-21. December 7, 1951. Ibid. 9008. December 11, 1951. 
disadvantage. Lacoste also welcomed that the treaty permitted compensation to businesses who suffered competitive pressures due to rising salaries.

The most emotionally-charged aspect of the ECSC ratification debates in the French National Assembly was the issue of labor migration. Article 69 of the ECSC treaty called for the free movement of coal and steel workers between national industries. Seconded at times by the right, French Communists made the specter of French migration to German industry the central thrust of their attack against the Schuman Plan. The ECSC, they charged, represented the realization of Hitler's dream of a Germandominated Europe and the ECSC would result in a new form of Fritz Sauckel's labor deportation program, with the free market doing the work once performed by Nazi occupiers. The polemical framing of this argument aside, the initial reaction of French Socialists displayed a different concern. At the May 1950 National Congress, Jouve and Mollet worried that high German unemployment would result in a flood of German workers into France, creating a downward pressure on wages ${ }^{25}$. Kurt Schumacher was also concerned that the ECSC would create a mass migration of German steel workers to France. Such assertions highlight the somewhat contradictory nature of SPD policy, as the free movement of labor within the OEEC zone was a demand the party had put forth since 1949, and continued to do so on the eve of the ECSC's ratification ${ }^{26}$.

At the French Assembly debate, Boutbien gave voice to the trade unions' fears of mass labor migration into France. However, he said that he was confident that the High Authority would be attentive to the social repercussions of any large-scale migration. The Labor Commission, he announced, called for the ECSC to establish an international card designating a workers' professional qualification before migrating 27. Across the Rhine, Birkelbach argued that migrant workers might suffer discrimination if the community did not adopt adequate safeguards ${ }^{28}$. The ECSC was ratified with the support of the SFIO by the French National Assembly on 13 December 1951, and over the strenuous opposition of the SPD by the Bundestag on 11 January 1952. French Socialists and German Social Democrats henceforth brought their critiques, proposals and evaluations of social protections for coal and steel workers to a new level: the Common Assembly of the European Coal \& Steel Community.

\footnotetext{
25 OURS, Congrès national, May 26-29, 1950.

26 AdsD, Bestand Rudolf Pass 14,Veit dch. H. Hermsdorf 7.12.51 Methoden der wachsenden Produktivitätssteigerung bei Aufrechterhaltung des gegenwärtigen Lebensstandards.

27 JO 1951. 8873. December 6, 1951.

28 Verhandlungen des deutschen Bundestages, 1.Wahlperiode. 7714-16. January 10, 1952.
} 


\section{SFIO and SPD Efforts on Behalf of Workers in the ECSC, 1952- 1954}

SPD leaders did not abandon their criticism of the ECSC during the Community's formative stage. Rather, they argued that the results of the first years of the ECSC confirmed the validity of their initial critique. Ollenhauer claimed in April 1954 that the negative effects of the community had even exceeded the fears that his party had expressed during the ratification period ${ }^{29}$. The party's delegates to the ECSC pursued this line within the Common Assembly. Wehner argued that employers and technocrats dominated the ECSC's operations. Joachim Schöne complained that the High Authority was proving itself ineffective and that the industries themselves seemed to have taken over decision-making ${ }^{30}$.

Despite this criticism, the party adopted a pragmatic approach to its involvement in the ECSC. As they had done after opposing West Germany's entry into the Council of Europe, once the Bundestag ratified the Treaty of Rome, the party sent delegates to the Common Assembly in an effort to attain and wield as much influence within the Community as possible ${ }^{31}$. The principal task that the party assigned itself in its dealings with the ECSC was to strengthen the power of the Common Assembly vis-à-vis employers' organizations and the High Authority. Here the French Socialist Party was an important ally, as it shared the goal of a greater democratization of the Community, which meant to French Socialists and German Social Democrats an extension of the Assembly's powers. During the constitutive session of the Assembly, Wehner insisted that the proposal of the Christian Democratic group to limit the number of Assembly committees would restrict the powers of the Assembly. He proposed to the Socialist Group a list of specialized committees to enable greater supervision of the Community's activities. Among these was a commission for work and social questions. Wehner's report became the official position of the Socialist Group, and this ensured the creation of a number of specialized committees in the ECSC Assembly ${ }^{32}$.

The High Authority proved not to be the intrusive, dictatorial body that many in the SPD had feared. In fact, the party's representatives tended to argue in the Common Assembly that the High Authority was not exercising enough power. Willi Birkelbach,

29 AdsD, SPD Parteivorstand 1954, Neuer Vorwärts April 9, 1954, «Gescheiterte Bonner Europapolitik».

$3^{30}$ IISH, Confederation of the Socialist Parties of the European Community (CSPEC) 28. January 13,1954 .

${ }^{31}$ AdsD, BEO 96, Ansprache von Erich Ollenhauer am Sonntag, dem 2. August 1953, 11,45 Uhr, im Sitzungsaal der SPD-Fraktion (Stadthalle-Hannover).

$3^{2}$ IISH, CSPEC 28, September 12, 1952. 
Gerhard Kreyssig, Joachim Schöne and Herbert Wehner criticized the High Commissioners on numerous occasions for not taking advantage of the full range of authority granted by the Treaty of Paris. What this approach seemed to imply was that the SPD did not view the High Authority to be discriminating against Germany in favor of French industry as they had previously argued that it would, though Gerhard Kreyssig condemned the High Authority for not taking sufficient measures to rectify the disadvantages with which German industry entered the Community33. Rather, the party feared more the effects of economic liberalism on the German working class. The treaty granted the High Authority the power to safeguard employment, promote and harmonize working and living conditions for workers, promote technical and economic research on occupational safety, help finance the re-adaptation of workers who suffered unemployment due to the competitive effects of the customs union, and ensure that the states did not create obstacles to the employment of other member states' workers 34 . The French Socialist and German Social Democratic parties set themselves the task of pressuring the High Authority to enforce these provisions with the greatest amount of haste and authority that was legally possible.

Adequate housing for workers had long been a priority for the French Socialist Party. The party wished to rectify the bias of the Monnet Plan towards heavy investment, which had left France with an increasingly acute housing shortage in the early $195{ }^{0}{ }^{35}$. The promise of Community-financed housing construction became the most conspicuous component of the ECSC's social program. Monnet promised the Assembly on multiple occasions that the High Authority would engage in a large-scale construction program ${ }^{36}$. In January 1954, Willi Birkelbach delivered a report of a subcommission of the Assembly's social affairs committee that had undertaken an extensive tour of workers' housing in the Lorraine, the Saarland, the Ruhr, Luxembourg, Limbourg and Liège. Everywhere the sub-commission had found «miserable lodging, houses in ruins, homes very distant from work sites, overpopulated housing». He told the Assembly that, «The misery that we found shocked us». He implored the High Authority to move quickly from its current investigation of housing conditions to immediate action. In addition, he asked that the construction program

33 Archive of European Integration (AEI), Communuaté Europeenne du Charbon et de l'Acier (CECA), Assemblée commune compte rendu in-extenso des séances. January 12, 1953.

34 SPIERENBURG, Dirk \& POIDEVIN, Raymond. The History of the High Authority of the European Coal and Steel Community: Supranationality in Operation, London, Weidenfeld and Nicolson, 1994, p. 175.

35 RIOUX, Jean-Pierre, The Fourth Republic, Cambridge, Cambridge University Press, 1987, pp. $175,181,190$.

${ }_{36}$ AEI, CECA. Assemblée commune, January 12, 15 1953, pp. 18-19. 
take close account of the material and social conditions of the workers, and that the High Authority should prevent long-term housing contracts linked to work contracts, which would give employers additional leverage over their workers. $\mathrm{He}$ also recommended that the housing program encourage the acquisition of property by workers but that it also be careful to ensure that the accompanying expenses not exceed workers' capacities. By way of example, he deplored the prospect of workers' children being unable to move from their regions to pursue studies because of the financial burden of property acquisition by their family37.

In 1954, the SFIO and SPD remained disappointed by the meager results of the ECSC housing program. After promising to build 50 to 60.000 houses in a year, Jean Monnet scaled back the project to 20 to 25.000 , having received a smaller loan from the United States than initially envisioned 38 .

French Socialists and German Social Democrats were also not satisfied by the efforts of the High Authority to achieve full employment, nor did they think that the Community provided adequate assistance to those workers displaced by the customs union39. Mollet told the Socialist International in February 1954 that the High Authority must immediately launch a re-employment policy with subsidies for lost work time, relocation and, eventually, the financing of professional re-education ${ }^{40}$. Mollet's speech followed a December 1953 request by the French government for High Authority financial assistance to redeploy miners from the Centre-Midi region to the Lorraine, after these mines closed due to the competitive pressures of the Community. In March 1954, the High Authority granted the French government 500 million francs for this program but few miners were willing to relocate ${ }^{41}$. No doubt aware of the results of this program, Guy Mollet called in June 1955 for the High Authority to finance the «reemployment on site in other businesses», communitarian assistance for the unemployed, and a guaranteed European minimum wage ${ }^{42}$.

SPD delegates, in turn, placed special emphasis on the precarious state of migrant workers. Louise Schröder reported that the High Authority had responded to her inquiries about the treatment of migrant workers by answering that this issue lay

37 Ibid. May 13, 1954, pp. 61-69.

38 SPIERENBURG, Dirk \& POIDEVIN, Raymond, op. cit. p. 180.

39 AdsD, Bestand Fritz Erler 7, Fritz Erler in Sozialdemokratische Pressedienst May 18, 1951, «Strassburger Zwischenbilanz».

40 OURS, Archive Guy Mollet (AGM) 106, Discours au Congrès de l'I.,. Les Autorités européennes, 23 Fevrier 1954.

${ }^{41}$ SPIERENBURG, Dirk \& POIDEVIN, Raymond, op. cit., op. 183.

42 OURS, AGM 106, Le Quotidien d'Informations politiques, économiques et sociales. 25 Juin 1955 «La Communauté doit être à l'avant-garde du progrès social» déclare à l'agence quotidienne Guy Mollet. By Louis Noblet. 
within the competence of the national states 43 . Birkelbach also raised this concern in the Common Assembly and called on the High Authority to create a European workers' passport, a periodic exchange of lists of available employment, an elimination of difficulties associated with relocation, and social loans to smooth migration 44 . SFIO and SPD deputies displayed an appreciation for the technical reports on social and economic conditions provided by the High Authority on this and other issues, which represented a difficult task due to diverging national conditions for gathering statistics. They demanded a larger budget to facilitate more extensive surveys of working and migration conditions, as well as statistics for professional maladies, workers' purchasing power, unemployment rates, and a comparison of salaries 45 . Such demands are all indicative of a desire for a more interventionist supranational authority in social policy.

One issue continued to dominate French Socialist policy toward the ECSC: the demand for the harmonization of social costs among the participating nations. The High Commission refused to take measures to equalize salaries among coal and steel workers, saying that the treaty did not grant them this power. French Socialist delegate Roger Carcassonne responded that varying wage levels represented an obstacle to free competition $^{46}$. At the 14 May 1954 meeting of the Socialist Group of the ECSC Assembly, Mollet succeeded in having his Socialist colleagues adopt the SFIO position. According to the resolution, the group demanded that the High Authority sponsor «a general conference of the six states with the purpose of establishing a convention to eliminate divergences between social legislation that cannot be corrected through collective bargaining»47. This policy area, like others mentioned above, remained unresolved when Belgian Socialist Paul-Henri Spaak gave his report at the Messina conference that launched the negotiations for a European Economic Community (EEC). When Guy Mollet became Prime Minister of France in 1956, his government demanded that the harmonization of social legislation be a central component of the negotiations for the Treaties of Rome, which set up the EEC. In varying forms, this demand remained a key demand of French Socialists up to the present day, and has recently become a more pronounced part of SPD policy on European integration.

43 AdsD, Bestand Carlo Schmid 1335, Bericht der Frau Abg. Louise Schröder über die gemeinsame Beratung zwischen der Hohen Behorde der Europäische Gemeinschaft für Kohle und Stahl und dem Ausschuss für soziale Frage der Beratende Versammlung der Europarates in Luxemburg am 29. Januar 1954.

44 AEI, CECA. Assemblée commune, May 13, 1954, p. 68.

45 AEI, B.A.I. Questionnaire sur le plan Schuman, undated. CECA Assemblée commune. May 13, 1954 69, 212.

46 SPIERENBURG, Dirk, POIDEVIN, Raymond, op. cit. p. 176.

47 IISH, CSPEC 28, May 14, 1952. 


\section{Conclusion}

The French Socialist and the German Social Democratic parties were dissatisfied by the accomplishments of the ECSC in the field of social policy in the mid-1950s. Having long supported supranationalism in principle, SFIO leaders fought to include an equalization of salaries and social costs in any program for economic liberalization. At the same time, a marked shift had occurred within the SPD's analysis of the High Authority. Having criticized the Schuman Plan for proposing a dictatorial body, the party delegates now criticized the High Authority for not aggressively pursuing social objectives. This assessment contributed to the party's ultimate decision to support the creation of the EEC, which also contained a supranational institution, the High Commission. It is likely that, having seen their chances of taking power at the national level diminish with the electoral loss of 1953, the SPD hoped to see some of its goals achieved within the ECSC, where it could perhaps gain greater influence over social policy. French Socialists and German Social Democrats were consistent critics of the paucity of the ECSC's social achievements in this period.

SFIO and SPD pressure for a more active social policy to aid the Community's workers was not without effect. In fact, a substantial number of SFIO and SPD proposals in the Common Assembly from 1952-1954 were put into place by the High Commission from 1955 until the merger of the High Commission with the EEC's institutions in 1967. Despite a slow start, the High Authority had helped finance the construction of over 77.000 houses for workers by 1964; it pressured the governments to sign a European Social Security Convention in 1957 that guaranteed equal benefits for migrant workers; after the crisis in the coal industry began, the High Authority succeeded in having the member governments amend the Treaty of Paris to allow it to assist coal and steel workers who became unemployed due to «fundamental changes... in market conditions», resulting in assistance to 162.000 displaced workers from 19601967, the majority of whom were German; and the High Authority increasingly sponsored research into occupational diseases, focusing especially on the impact of high temperatures and dust 48 . The harmonization of social charges, however, remained elusive.

Although this last point remains beyond the scope of this article, there is little doubt that SFIO and SPD pressures in the ECSC led over the long term to a smoother and less socially damaging de-industrialization process as crisis hit the west European coal and

${ }^{48}$ SPIERENBURG, Dirk, POIDEVIN, Raymond, op. cit. pp. 331-332, 547, 553, 637. 
steel industries. Designed initially to modernize and expand coal and steel production, the High Authority instead spent much of its existence managing the decline of Western European heavy industry and shielding the sectors' workers from the devastating impact of sudden, insurmountable unemployment. 


\section{* L'autore}

Brian Shaev is a doctoral candidate in Modern European History at the University of Pittsburgh. His dissertation research analyzes the attitudes and policies of the French Socialist Party (SFIO) towards Germany and European integration, as well as that of the German Social Democratic Party (SPD) vis-à-vis France and Europe in the years leading to the formation of the European Economic Community (EEC). This research focuses on the importance of inter-party relations and the background and ideas of the parties' leaderships while seeking to balance ideological considerations with the parties' evolving geopolitical conceptions and priorities in their respective processes of policy formation. He has also been researching how French and West African political elites sought to remake the French-West African colonial relationship in the context of colonial war, decolonization, and programs for European unity.

URL: < http://studistorici.com/progett/autori/\#Shaev >

\section{Per citare questo articolo:}

SHAEV, Brian, «The French Socialist and German Social Democratic Parties and the Future of the Working Class in the European Coal \& Steel Community, 1948-1954», Diacronie. Studi di Storia Contemporanea: Quando la classe operaia andava in paradiso, 13/2/2012,

URL:<http://www.studistorici.com/2012/02/13/shaev_numero_9/ >

Diacronie Studi di Storia Contemporanea $\beta$ www.diacronie.it

Risorsa digitale indipendente a carattere storiografico. Uscita trimestrale. redazione.diacronie@hotmail.it

Comitato di redazione: Marco Abram - Giampaolo Amodei - Jacopo Bassi - Luca Bufarale - Alessandro Cattunar - Alice De Rensis Barbara Galimberti - Deborah Paci - Fausto Pietrancosta - Martina Sanna - Matteo Tomasoni - Luca Zuccolo 